\title{
Fantasy Themes in Peasants Movement
}

\author{
A. Pratiwi ${ }^{1}$, S. Sarwoprasodjo ${ }^{2}$, E. Soetarto ${ }^{3}$, N. K. Pandjaitan ${ }^{4}$ \\ \{aprilyantipratiwi@univpancasila.ac.id ${ }^{1}$, sarwititi@gmail.com ${ }^{2}$, endriatmo@yahoo.com ${ }^{3}$ \} \\ ${ }^{1}$ Faculty of Communication Science Pancasila University, Indonesia \\ ${ }^{2,3,4}$ Department of Communication Science and Community Development IPB University, Indonesia
}

\begin{abstract}
Land destination is ideally for people's welfare but it is actually under the control of some corporations. As a result, land conflicts increase year by year in Indonesia. However, these are frequently overlooked. Despite the land conflicts are handled, these discredit peasants. The peasants are the ones who always get lost when their opponents are large corporations or the government itself. Therefore, the birth of peasants' resistance movement is a form of their defense and rebellion. A peasant resistance movement in Indonesia is the peasant movement carried out by STTB (United Telukjambe Peasants Association). The STTB association carried out a suicide action in front of Presidential Palace. It was the most extreme action that Indonesian peasant unions had ever done. The research goal is to analyze fantasy themes that the STTB peasants have when they have physical clashes with PT. Pertiwi Lestari. The theory used in this research is the Symbolic Convergence Theory with the Basic Concept level. The research method is a qualitative case study approach. The research analysis in this paper is Fantasy Theme Analysis (FTA). The data collection techniques in this research are the Forum Group Discussion (FGD), interviews and observations. The research results show that the fantasy themes that the STTB peasants have are a common fate, a feeling of togetherness, freedom to work on land and to own house, fighting for land rights. These fantasy themes can be used as communication strategies and therefore, the STTB peasants become more solid and integrated.
\end{abstract}

Keywords: Symbolic convergence theory, fantasy themes, peasants resistence movement

\section{Introduction}

The End-of-Year Notes from KPA (The Agrarian Reform Consortium) show an increase in the number of land conflicts annually. The increase in the number of land conflicts will be followed with violence cases that the peasants experience. The old conflicts have not ended, new conflicts are born. The change from the presidential era of SBY to Jokowi becomes the beginning. The KPA data recorded 472 land conflict cases in 2014. These decreased to 252 land conflict cases in 2015. However, the number of land conflicts has increased twice as much to 450 cases in 2016. The land conflicts increased again to 659 cases in 2017 [1].

Moreover, what about the number of land conflicts that has occurred in 2018? Based on the KPA records, it is found that there had been 410 cases of land conflicts in Indonesia in 2018. In fact the number of land conflict cases in 2018 has decreased if compared to the previous year and the decline is not an achievement that we have to be proud of. The number of land conflict cases from year to year is a chore and it is very difficult to resolve. Particularly in 2019 it is this political year. The central government is definitely busy and it has to take preprare before the 2019 Presidential Election for the five-year event success. Once again, the land conflict casess have been neglected. 
It was definitely remembered that in the Presidential Candidate Debate in February 2019 in the 2019 Republic of Indonesia Presidential Election, the President Candidate Number One, Joko Widodo accused Prabowo Subianto, his competitor mastering HGU (Cultivation Right on Land) with hundred thousands of hectares. Prabowo replied that there were several Taipan supporters of Joko Widodo having the Cultivation Right on Land with larger land areas (bbc.com). This mutual accusation occurred between the two candidates and it made the community participating in the debating of the Cultivation Right on Land issues. In fact the Cultivation Right on Land is under the control of some businessmen. It is very clearly written in Article 33 Paragraph (3) of the 1945 Constitution that "the earth and water and natural resources contained therein shall be controlled by the state and be used for the greatest prosperity of the people".

A number of previous researches finds that land conflicts in Indonesia generally occur between land workers and the private sector and / or government [2]-[8]. Syafi'i [9] explains that a high number of land conflicts in Indonesia shows our poor management of natural resources. Moreover, Palupi et al [10] states that the main cause of land conflicts relates to mal-administrative practices that occur in the field. This results in the removal of community rights to land and damage to the environment.

Land has a very important meaning for the life of mankind to meet their needs [11]. It is why when other parties disturb the peace of the community over land ownership, they will make a movement as part of their resistance to land disturbance [3], [12]-[21]. A case that has caused a peasant resistance is Teluk Jambe land conflict case, Karawang. Telukjambe had ever become the highest rice barn region in West Java. Now it changes when agricultural land has been converted to industrial estates. As land conversion occurs in Telukjambe, the land conflict cases arise. The land conflict had seized public attention and President Jokowi in 2017 when Telukjambe peasants under the flag of the STTB association (United Telukjambe Peasants Association) carried out longmarch from Karawang to Presidential Palace in Greater Jakarta. The association willingly took a more extreme action, such as a self burying action in front of Presidential Palace.

As community members, we can argue that the extreme actions taken by the STTB peasants are useless. However, they must do the collective action. These have become a mandatory action for the peasants. Before the STTB peasants buried themselves in the grave, we witnessed how the Kendeng villagers had done the foot casting action in front of Presidential Palace [22], [23].

Moreover, what causes did the STTB peasants carry out the collective actions? Why did the STTB peasants volunteerly take action to bury themselves in front of the Presidential Palace? In a group or organization, it needs a convergent communication, i.e. the unified communication through several symbols or messages exchanged each others by communication participants who have the same vision. The authors assumes that peasants who are members of the STTB association convergently communicate with their leaders through fantasy themes. The dramatization of messages through jokes, stories, analogies, the metaphor as revealed by Stewart et al [24], has an effect on the high solidity among the STTB peasants. This research is quite important because it considers that current function of the State is no longer dominant and therefore, the association's social movement is born. Therefore, the researchers are interested in analyzing fantasy themes owned by the STTB peasants.

After the researchers have made some searching, there are several previous studies that have used the Symbolic Convergence Theory. Armstrong [25] uses the Symbolic Convergence Theory when he analyzes problems in the education field. He studies fantasy themes in the student learning groups when they prepare for global competition. In other 
fields, the Symbolic Convergence Theory is found in a Sulistyani's research [26]. She examined the meaning of Indonesian girls in Disney films. The research was analyzed using the perspective of mass media studies. Heriyanto [27] combined new media and political communication research in his dissertation with the title of "Symbolic Convergence in the Virtual Community". The Symbolic Convergence Theory is also used to examine social movements, such as Angeline's research [28]. The research analyzed the movement of the Ahok supporters community who had collected one million Residence Identity Card.

Based on the literature review of previous researches it is known that so far there has been no research that uses the Symbolic Convergence Theory to analyze the peasant resistance movement. Therefore, this research is conducted to make the contribution of using the Symbolic Convergence Theory in the peasant movement research.

\subsection{Research Methods}

The research method used in this research is a qualitative case study approach. Bormann explains that one method used generally in the writing with the Symbolic Convergence Theory is a case study [29]. Yin [30] explains that there are four case study cases, i.e. single-case and multi-case holistic case studies, intertwined single case studies and multi-case intertwined studies. Based on the four types of the case studies according to Yin, this writing is included in the type of intertwined single case study. This writing chooses the peasant resistance movement case carried out by the STTB association as an effect of agricultural land seizure and displacement from their arable land and homes. This case is an extreme case. The STTB association carried out several collective actions and these could be categorized as extreme ones, i.e. together blocking heavy equipment in the eviction process, longmarch from Karawang to Presidential Palace in Jakarta and the self grave action in front of Presidential Palace.

The data collection techniques carried out for this writing were the Focus Group Discussion (FGD), in-depth interviews and observations. The FGD was conducted with the participants of 10 STTB peasants who had been evicted due to the land conflict case with PT Pertiwi Lestari and Perum Perhutani. The in-depth interviews were conducted to eight STTB peasants who were involved in the physical conflict and the eviction of PT Pertiwi Lestari. The observations was made when the researchers directly observed the land conflict location and followed some activities of the STTB peasasnts regarding their peasant resistance movement.

Bormann explains that the Symbolic Convergence theory is constructed within the framework of the narrative paradigm. The narrative paradigm has the belief that humans are storytellers or homo narrans. Humans describe and share events that they experience through narratives or stories [31]. Based on Bormann's statement, when finding out how the fantasy themes of the STTB peasants, the researchers explore the data by listening the stories shared by the STTB peasants regarding their land conflict experiences, particularly during the physical conflict and eviction of PT Pertiwi Lestari. The researchers did not make interview questions in detail but simply listened their stories while keeping them within the corridor of the Symbolic Convergence Theory.

In this research, the data analysis techniques will be carried out by using Fantasy Theme Analysis (FTA). Borrman [32] states that the Symbolic Convergence Theory can be operationalized by using Fantasy Theme Analysis (FTA). It has four processes, i.e., fantasy themes, fantasy chains, fantasy types and rhetorical visions. 


\section{Research Result and Discussion}

The Symbolic Convergence Theory is a theory that Ernest Bormann, John Cragan, and Donald Shield had been developing. Based on Bormann's explanation, this theory is a communication theory that describes humans and their groups who together constructing a symbolic awareness that has significant meaning which ultimately builds emotions and motives for action [33]. In relation to this theory, Bormann further states that members who are part of a group membership are obliged to exchange fantasies to form a unified group. According to Bormann et al. in this theory, fantasies are stories or jokes that contain emotions or even express emotions as well [31]. The Symbolic Convergence Theory has six basic components, i.e. basic concept, message concept, dynamic concept, communicator concept, medium concept and evaluative concept. Based on the explanation of the Symbolic Convergence Theory, the researchers find that the STTB peasants in their life experience when having the land conflict with PT Pertiwi Lestari construct a meaningful symbolic awareness. The meaningful symbolic similarity is definitely able to arouse the emotions of the STTB peasants to establish motive for them to act.

Cragan and Shield explain that the basic concept is an analysis unit of the Symbolic Convergence Theory [34]. The Basic concepts in the Symbolic Convergence Theory are the fantasy themes, symbolic markers, fantasy types, and saga. In this research, we will only analyze the basic concepts at the level of fantasy themes with the help from the analysis unit of the fantasy themes.

\subsection{The Fantasy Themes of STTB's Fighting Movement}

There are several fantasy themes that the STTB peasants members have to arouse their enthusiasm in encountering the land conflict with the company.

\subsubsection{The Fantasy Themes: A Common Fate and A Feeling of Togetherness}

The story begins with the awareness of Cisadang Villagers, Telukjambe Barat, East Karawang, West Java. They realized that they had experienced an unusual condition. In one morning, their access road to and from outside the village was suddenly blocked. Several men wearing security guards made the portal block. A signpost was immediately installed and the boundary walls were built around their village. What it is written on the sign is that the land is under the authority of PT Pertiwi Lestari HGB. No. 5, 11, 30. On the sign it prohibits anyone from entering or working on the land area without any permission from the company.

If it violates, it will get sanctions according to the Article 167 Paragraph (1), Article 385, and Article 406 paragraph (1) of the Criminal Code. At the bottom of the signpost it is written that "Anyone who revokes/damages this signpost shall get criminal sanctions ".

Some residents tried to find explanation about the conditions they were experiencing. The road closure, wall construction and signpost installation seemed sudden and there was no prior notice. They did not get any explanation on this matter and even some public figures were criminalized. The first conflict began in 2010. At that time several peasants were reported to the authorities. They were accused to replace the signposts. Starting from the matters, the peasants began to realize that they were in a conflict situation.

This situation had made peasants and community in the villages unite together into the Unified Peasants Association. The members felt that they had some similarities, i.e. the common fate of the land conflict experience. Until 2014 the peasants and the community experienced an uncertain situation. Moreover, they agreed to preserve their togetherness in an 
organization. After the organization got ratification from a Notary, the organization was called the United Teluk Jambe Peasants Association or the STTB. From the explanation of Kang Maman as General Chairman of the association, the establishment was firstly intended to maintain the agricultural land for the peasants.

The STTB peasant members not only came from peasants from Cisadang Village. Some peasants and communities from other villages who experienced the similar land conflicts also joined with the STTB. As the STTB Advisory Board, Mas Aris explained that at that time STTB was home for 12 villages, i.e. Kiarahayam, Cikebo, Cibinong, Cisuba, Pasir Cabe, Cibungur, Cibadak, Cikamuning, Cijengkol Village. Twelver villagers felt that they shared a common fate, i.e. the land conflict experience despite their enemies came from different parties. Cisadang Villagers were in conflict with PT Pertiwi Lestari while several other villagerss were in conflict with Perum Perhutani.

The common fate was continuously conveyed to its members, and Mas Aris dramatized and gave some parables. Mas Aris narrated the importance of their togetherness as well as their unity and union. According to Mas Aris, the togetherness was the key to success. He also invited its members to strengthen the togetherness by holding some meetings, i.e. the internalisation meeting, the coordination meeting and the general meeting. The last meeting was the largest one. It was held once a week and it would involve peasants from 12 villages. During the meeting Mas Aris narrated that how common fate and togetherness were a very good combination in encountering their enemies. In relation to narratives with the themes of togetherness as well as unity and union, Mr. Aris also conveyed to his members concerning the traditional customs of the Indonesian people, i.e. mutual cooperation and supporting each other. He emphasized that the STTB peasant members must have the mutual cooperation and supporting each other particularly when dealing with this land conflict.

Concerning the The narrative which contains the messsage dramatization of common fate and togetherness, it got response from the STTB peasants. The response could be seen from the joining of peasants from 12 villages in a forum that they believed it could fight for their aspirations regarding the land conflict they were encountering, i.e. the STTB assocaition. The response to the dramatization on the importance of togetherness could be seen from a number of members who always came in every meeting held by the STTB association.

\subsubsection{The Fantasy Themes: Freedom to have a place to live and work on land}

The STTB peasants stated that their freedom to have a place to live and work on agricultural land had been seized. Since 2007, the peasants had admitted that they had been colonized. At that time Perum Perhutani forcibly planted by their land with sengon seeds. Wanajaya villagers experienced it. They did not understand what they were experiencing at that time. Perum Perhutani did not say anything about the actions they took on the land.

Cisadang and Kiarahayam villagers also experienced the freedom to have a place to live and work on land. Their freedom to work on land culminate in early August 2016. At that time when some members of Brimob special police unit accompanied, PT Pertiwi Lestari came to Cisadang and Kiarahayam villagers. They came and carried heavy equipment. As one of the STTB members who was present in the incident at the location, Pak Bodeh told me that as far as he remembered, there were a thousand members of Brimob special police unit who came to their villages. They stayed at their residential and agricultural land area. Mr. Bodeh and other STTB members felt very uncomfortable with the existence of Brimob special police unit. According to Mrs. Mila, they sometimes came to people's residents and engaged in conversations with the residents. In the conversation, they persuaded the residents to surrender and receive the compensation from PT Pertiwi Lestari. 
According to stories from the STTB members, they have rights to the land they live in and work on. They have lived there for one generation to another generation. Mas Aris admitted that he had a chance to trace the disputed land. He found several documents and the documents explained that the land at fist had the perfounding ownership of CV Tegalwaru London in 1928. Moreover, it was nationalized since Indonesia's independence after the Law Number 5 Year 1950 prevailed. Moreover, it prevails Basic Agrarian Law concerning the nationalization of Foreign Assets returned to Indonesia.

According to Mas Aris, based on this condition the community also had right to propose the legality of this land ownership. However, in reality this legalization submission was not responded particularly from Karawang Regional Government. Moreover, there were actually claims from PT. Pertiwi Lestari for industrial expansion. It had the pretext that they had HGB (Building Use Right Certificate) as the result of taking over the Land Use Right (HGU) from PT. Tanjung Gresik Makmur.

With the hand of the Building Use Right Certificate (HGB), PT Pertiwi Lestari frequently puts pressure and persuasion on peasants and villagers whose areas are included in the map that PT Pertiwi Lestari has claimed. Instead of using Brimob to pressure peasants and villagers, PT Pertiwi Lestari also told several parties to suppress and persuade peasants and villagers to surrender and move from the existing land area. They persuaded them with some compensation money from PT Pertiwi Lestari. The STTB association called it such a compensation money. The association considers that the money from PT Pertiwi Lestari is worthless if compared to their land they have cultivated and planted with full struggle, love and affection all this time. However, there are some peasasnts and villagers who have surrendered. They have received the compensation money and would leave the land.

In the coordination meeting and general meeting Mas Aris frequently dramatized the importance of freedom. The freedom to have a place to live and cultivation. This is what makes the peasant members more exciting. Despite they had different enemies, but their vision and mission were the same, i.e. returning to work on the land and have a place to live freely as before. Mas Aris continuously dramatized this message while sitting relaxed with its members in a coffee shop.

The STTB members responded to the message dramatization. The response to the message dramatization was to remain on their rice field that they believed as their land. They did not care, particularly when PT. Pertiwi Lestari tempted them a compensation. They consistently rejected the compensation with total value of Rp. 30,000,000 per peasants. They believed that there were many people who became the extension of PT Pertiwi Lestari, and they tried to persuade them to accept the money and move to another place. However, they persevered on their current home and land.

\subsubsection{The Fantasy Themes: The Peasants Fight Against Their Land Rights}

When the rally was held, Kang Maman (Kang is Sundanese calling for an older man) did not get tired of calling on his members on the importance of the land for the peasants. He assured his members that the disputed land was definitely their rights and theirs. $\mathrm{He}$ analogized that if the STTB peasants were displaced from the land area of 791 hectares where they had occupied until now, they would not have land for their cultivation and shelter. If PT Pertiwi Lestari destroyed the land where they had been working on for a long time and did not provide inadequate compensastion. If they did, 1,800 peasants will automatically be miserable at that time. But Kang Maman convinced his members to stay and continue to fight against the land conflict. He had consolidated this matter with his members for their land rights. He also 
invited his members to sue the government. It was considered that the government was reluctant to revoke the HGU (Cultivation Right on Land) of PT Pertiwi Lestari.

The STTB peasant members responded to the dramatization of the message that Kang Maman had conveyed. They had come to the office of Agrarian and Spatial Planning Ministry/National Land Agency in 2015. They asked the Ministry to resolve the land problem that they had experienced. They asked the Ministry to immediately issue the land certificate they had had for many years. However, Karawang Regent agreed to issue the land certificate for the community in the 12 villages in 2003.

The response to the dramatization of this message can also be seen in the second physical conflict between the STTB association and PT Pertiwi Lestari. It occurred on October 11, 2016. The peasants and people of Teluk Jambe did not accept their land that PT Pertiwi Lestari executed using heavy equipment. Fights are inevitable. Hundreds of peasasnts and community united against the company's security. That morning, at 10:00 WIB, suddenly several heavy equipment entered the village of Cisadang. Hundreds of the STTB peasants members immediately arrived and immediately joined hands and formed a chain and advanced to block the heavy equipment. This heavy equipment destroyed plants that they had planted with difficulty.

On the other hand, the STTB women peasants made a line to block PT Pertiwi Lestari. In this event, PT Pertiwi Lestari brought along a large number of a special police unit members (Brimob). Chaos occurred when one of the heavy equipment knocked down a tree and it almost hit one of the residents' houses. The STTB peasant members felt angry. Moreover, they approached PT. Pertiwi Lestari. The scuffles were inevitable. Instead of intervening and securing the atmosphere, Brimob members made the atmosphere more gripping when they fired multiple shots in the air.

Table 1. Themes of STTB Peasants

\begin{tabular}{|c|c|}
\hline Fantasy Themes & Rhetorical Context \\
\hline $\begin{array}{l}\text { A common fate and a feeling of } \\
\text { similarities }\end{array}$ & $\begin{array}{l}\text { - Conveyed during the public meeting in } \\
\text { a kind of saying a parapble } \\
\text { - The response to the statement is that } \\
\text { peasants from } 12 \text { villages join with the } \\
\text { STTB association. }\end{array}$ \\
\hline $\begin{array}{l}\text { Freedom to have land for cultivation } \\
\text { and home }\end{array}$ & $\begin{array}{l}\text { - Conveyed during the public meeting } \\
\text { - The response to the statement is keep } \\
\text { staying on the arable land and refusing } \\
\text { the compensation that PT. Pertiwi } \\
\text { Lestari has offered }\end{array}$ \\
\hline $\begin{array}{l}\text { Fighting for land rights for the } \\
\text { peasants }\end{array}$ & $\begin{array}{l}\text { - Conveyed in the public meetings when } \\
\text { they met in leisure time at a coffee } \\
\text { shop/the houses of the STTB peasant } \\
\text { members } \\
\text { - response the STTB members have gave } \\
\text { is providing resistance in physical } \\
\text { conflicts with PT Pertiwi Lestari }\end{array}$ \\
\hline
\end{tabular}

Borman explains that in difficult conditions, humans will usually share fantasy. Through the act of sharing the fantasy, humans feel satisfied with this experience [34]. This is what happens to peasants of the STTB members. They experienced difficult times for years due to 
the land conflict with the company. For their experience in dealing with this land conflict, they shared fantasy. Bormann states that the fantasy themes are the dramatized messages and these are usually in a kind of jokes, analogies, word plays, and encouraging stories to interact each other within the groups [24].

In view of a communication perspective, social movements are formed through the convergence or unification of various symbolic dimensions which include actors in the movements. One important aspect to be observed in the communication dynamics of social movements is how these symbols are exchanged each other by the involved actors and therefore, the STTB resistance movement is established. Borman and his team in Minnesota explore the convergence of people around symbolic fantasy themes. Straightforwardly, fantasy themes are understood as dramatized messages. The messages can be a play on words, stories, analogies, or speeches. This dramatized message is believed to generate interaction in a group.

There were dramatized messages and analogous messages that the STTB leaders had made. At each meeting and in a leisure time among the peasants, the STTB leaders always conveyed the dramatization and analogy of the message in relation to the land conflicts that the STTB peasants were involved. The dramatization and analogy of this message are in Bormann's call as a fantasy theme.

The fantasy theme of "a common fate and a feeling of togetherness" was conveyed by the STTB leaders in several meetings that they had arranged. The message conveyed during a speech of this meeting got response from the STTB members when 12 villages joined in the STTB association. The fantasy theme of "Freedom to have a place to live and work on land" was also conveyed during the meeting. From the fantasy theme, the STTB peasants members showed their resistence response in the dispute land and rejected the compensation from PT Pertiwi Lestari. Moreover, in the next fantasy theme is "Fight for land rights for peasants", the response of the STTB peasant members was shown in the culmination of their struggle, i.e. fighting against the execution of PT Pertiwi Lestari to the land they had lived and worked on for many years.

When a group shares symbols, the communication becomes easy and right on target. It occurs when a phenomenon occurs and it is called Infante as quoted from Suryadi [31] as "a meeting of mind". "A meeting of mind" explains that when people's minds meet each other, they will move towards using the same symbol method. The use of this symbol method at the next level will result in increased mutual understanding among these peasants. This mutual understanding at a later stage becomes the foundation for the formation of shared awareness, mind awareness and feeling awareness about what is being discussed.

"A meeting of mind" occurs to the STTB peasants. The similarity of symbols shared by their leaders at the STTB association was able to make them equate perceptions about what they had experienced at that time. Through the use of emotive sentences, the STTB leaders succeeded in increasing mutual understanding among the STTB peasants members. The condition of conflict and powerlessness had succeeded in arousing the peasants' emotion. On the other hand, the destruction and eviction of their homes and rice fields carried out by PT. Pertiwi Lestari made them angry and disappointed. The STTB peasants constructed the emotions together. The feeling of "anger" and "disappointment" that they felt was not formed because their selves require it but due to a common fate that they experienced, the similarities of the symbols that they had exchanged each other and the similarity of identity that they already had had.

The fantasy themes can be used to foster and maintain the cohesiveness of a group, as found in the research conducted by Kusumajanti [35]. The cohesiveness that occured in the Moro 15 Association of the Indonesian Navy was formed through the fantasy themes that they 
have shared. In this research it is found that the positive interpersonal relationships intertwined in a group can create effective communication activities and it results in a good response to the fantasy themes that they shared in the group.

The fantasy themes are also found in the Muslim-Chinese group in Makassar. The fantasy theme they have used aims to increase the attachment to the symbol's use. The attachment of this symbol makes the Muslim-Chinese group in Makassar has an empathetic nature and has an identity that distinguishes them from other groups. One of them is the use of sign symbols to unite the thoughts of each group member. This equation of thoughts definitely will strengthen the solidarity among its members.

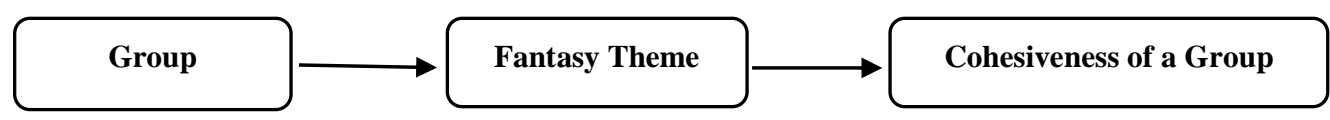

Fig. 1. Group's Fantasy Themes Fantasy

The same is true for the STTB peasants members. The similarity of symbols in the fantasy themes when they use is an effort to strengthen the relationship each other, to form cohesiveness in the peasant resistence movement group. Therefore, the red thread can be drawn that the fantasy themes in the group are an awareness that each member have about the similarities they have with other group members. The similarities will foster mutual ownership among them. This sense of belonging will foster cohesiveness.

\section{Conclution}

The fantasy themes of the STBB association are a common fate, a feeling of togetherness and freedom to have a place to live and work on land, and fight for land rights for peasants. The fantasy themes can be used as a weapon to see the communication strategies carried out by the STTB association to further unite them in fighting against the land conflicts. These need further researches to find out how the roles of the related parties. In this matter, the related parties include Karawang regional government, the central government and other related parties in the story of the STTB peasants' struggle in fighting against the land conflicts with PT Pertiwi Lestari.

\section{Acknowledgements}

Many parties have helped the author in completing this writing. I would like to thank the chairman of the promoter and the promoter members who have guided the author. Thanks to Mrs. Sarwititi, Prof. Amo and Mrs. Mala for the guidance and attention that has been given. The author also said thanks to the Faculty of Communication Sciences, Pancasila University, which has provided support to the author both morally and materially. I also would like to thank LPDP BUDI DN for providing scholarships for the duration of the author's doctoral study at IPB University. Hopefully the results of this paper can contribute scientifically in enriching the study of the peasant movement in general and and the communication of the peasant movement in particular. 


\section{References}

[1] "Final Note in 2018 Consortium for Agrarian Reform: The Future of Agrarian Reform Beyond the Year of Politics," in [KPA] Konsorsium Pembaruan Agraria Indonesia, 2019.

[2] A. Badrah, "Advocacy evaluation of resolving land dispute conflicts in Banggai District, Central Sulawesi," J. Stud. Pemerintah, vol. 2, no. 2, pp. 219-236, 2011.

[3] M. Fajrin, "The dynamic of the peasant movement: its emergence and sustainability (Banjaran village, Banjarsari District, Ciamis District)," IPB University, 2011.

[4] S. Kalo, Under the stranglehold of capitalism. Indonesia: USU Library, 2004.

[5] L. G. Atek, "The struggle of local communities in the midst of developing iol palm land (Case studies of oil palm community in Wambes village, District Arso, District Keerom, Papua Province)," J. Stud. Pembang. Interdisiplin, vol. 13, no. 1, pp. 19-31, 2014.

[6] A. M. Koesume, "Dispute Protected Forest Areas between Perhutani and the Kemloko village community in Tembarak district, Temanggung Regency," Unnes Law J., vol. 3, no. 1, pp. 1-9, 2014.

[7] L. Septiani, "Analysis of land conflict between Karawang farmer and PT. Pertiwi Lestari (Case in Wanajaya village farmers, West Telukjambe District, Karawang Regency, West Java Province),” IPB University, 2017.

[8] Y. Fahrimal, "Strategic Communication in Agrarian Conflict Resolution in Indonesia," J. Ris. Komun., vol. 1, no. 1, pp. 109-127, 2018.

[9] I. Syafi'i, “Agrarian conflict in Indonesia: A Reflective Note on the conflict of oil palm plantations in East Kontawaringin," J. Masy. dan Budaya, vol. 18, no. 3, pp. 415-432, 2016.

[10] S. Palupi, "Plantation industry and human rights: A potrait of the implementation of government and corporate responsibility for human rights in Central Kalimantan," in The Institute for Ecosoc Rights, Indonesia, 2014.

[11] M. Zakie, "State Authority in Land Procurement for Public Interset in Indonesia and Malaysia," in Litera,Indonesia, 2013.

[12] A. Mutolib, "Agrarian conflict and release of ulayat land (A case study of Malay Tribes in the Dharmasraya forest stake unit, West Sumatra)," J. Penelit. Sos. dan Ekon. Kehutan., vol. 12, no. 3, pp. 213-225, 2016.

[13] A. Pratiwi, "Social conflict and and community social movement," in E-Proceeding Comicos 2017, 2017, pp. 753-790.

[14] Hartoyo, "Involution of the agrarian movement and farmer's fate," IPB University, 2010.

[15] R. Kamajaya, Transformation of the farmer movement strategy. 2010.

[16] S. A. Kamaruddin, "Unra Peasant Rebellion 1943," J. Makara Sos. Hum., pp. 19-35, 2012.

[17] R. Yunike, “Omah Tani political social movement in Batang regency," J. Polit. Muda, vol. 1, no. 1, pp. 23-34, 2012.

[18] R. Taib, "Development conflict and new social movement (Efforts to understand changes in movement identity from 'farmers' to community)," IPB University, 2014.

[19] S. Kartodirdjo, The revolt of peasant Banten 1888 (Indonesian version). Komunitas Bambu, 2015.

[20] Mawardji, "Farmers resistence against agrarian injustice in the stigma of the security disruptive clan (Study in the Talangsari society in East Lampung)," IPB University, 
2016.

[21] J. Santoso, "Farmers movement in demanding land rights (Case in Cipari, Cilacap, Central Java)," UGM, 2016.

[22] G. A. Pengayom, "Resistance movement of the Rembang mountain community towards the construction of the Semen Indonesia Plant in 2014-2017," J. Polit. Gov. Stud., vol. 6, no. 4, 2017.

[23] D. Puspitasari, “Women's movement against mining corporation (Gender perspective study in North Kendeng Mountains, Gunem District, Rembang Regency, Central Java Province)," Airlangga University, 2017.

[24] J. C. Stewart, Persuasion and social movements. USA: Waveland Press, 2012.

[25] E. M. Amstrong, "The use of fantasy theme analysis to describe the group communication and creative problem solving's kills of university-level students as they prepare for destination imagination global finals competition," Andrews University, 2015.

[26] H. P. Sulistyani, "Local meaning of global texts through analysis of fantasy themes," J. Ilmu Komun., vol. 13, no. 2, 2016.

[27] G. G. Heriyanto, "Symbolic convergence in virtual communities: A study of new public spaces in political communities in social networking sites and interactive weblogs the age of SBY-Boediono's government in the century case," Padjadjaran University, 2013.

[28] M. Angeline, "Symbolic convergence in a social movement: a case of 'Pengumpulan satu juta KTP' by teman Ahok," Humaniora, vol. 7, no. 4, pp. 535-543, 2016.

[29] A. Venus, "Ernest Bormann and Symbolic convergence theory," J. ISKI Bandung, vol. 1, no. 1, 2007.

[30] K. R. Yin, Case study: design and method. Indonesia: PT. Raja Grafindo Persada, 2019.

[31] I. Suryadi, "Symbolic convergence theory," J. Acad. Fisip Untad, vol. 2, no. 2, pp. 426-437, 2010.

[32] Bormann, "E.Symbolic Convergence Theory: A Communication Formulation," J. Commun., vol. 35, pp. 128-138, 1985.

[33] Arianto, "Fantasy theme in group communication Moslem-Tionghoa," J. Ilmu Komun., vol. 10, no. 1, pp. 1-12, 2012.

[34] D. Kartikawangi, "Symbolic convergence theory in literature review," InterAct J. Commun., vol. 2, no. 2, pp. 71-81, 2013.

[35] Kusumajanti, "Development of fantasy theme in maintaining interpersonal relationships, and group cohessivenes: analysis of the "Esprit de Corps" fantasy themes among retired men (Study at the Moro 15 association of the Indonesian Army)," Universitas Indonesia, 2015. 